\title{
Feeding by heterotrophic dinoflagellates on the common marine heterotrophic nanoflagellate Cafeteria sp.
}

\author{
Hae Jin Jeong ${ }^{1, *}$, Jeong Eun Song ${ }^{1}$, Nam Seon Kang ${ }^{1}$, Shin Kim², Yeong Du Yoo ${ }^{1}$, \\ Jae Yeon Park ${ }^{3}$
}

\footnotetext{
${ }^{1}$ School of Earth and Environmental Sciences, College of Natural Sciences, Seoul National University, Seoul 151-747, ROK

${ }^{2}$ Department of Oceanography, Kunsan National University, Kunsan 573-701, ROK

${ }^{3}$ Research Institute of Oceanography, College of Natural Sciences, Seoul National University, Seoul 151-747, ROK
}

\begin{abstract}
To investigate interactions between heterotrophic dinoflagellates (HTDs) and heterotrophic nanoflagellates (HNFs), we tested whether or not 5 HTDs (Oxyrrhis marina, Gyrodinium cf. guttula, Pfiesteria piscicida, Luciella masanensis, and Stoeckeria algicida) feed on the common HNF Cafeteria sp. and measured the growth and ingestion rates of O. marina, G. cf. guttula, and P. piscicida when feeding on Cafeteria sp. (equivalent spherical diameter $=$ ca. $3.5 \mu \mathrm{m}$ ). We calculated grazing coefficients by combining field data on abundances of $O$. marina and G. cf. guttula and co-occurring HNFs with laboratory data on ingestion rates obtained in the present study. O. marina, G. cf. guttula, P. piscicida, and L. masanensis were able to ingest Cafeteria sp., while $S$. algicida did not feed on it. Cafeteria sp. supported positive growth in O. marina and G. cf. guttula, but not in P. piscicida. Specific growth rates of $O$. marina and G. cf. guttula on Cafeteria sp. increased with increasing mean prey concentration before becoming saturated at the mean prey concentration of ca. $100 \mathrm{ng} \mathrm{C}$ $\mathrm{ml}^{-1}\left(20000\right.$ cells ml$\left.l^{-1}\right)$. The maximum growth rates of $O$. marina and $G$. cf. guttula on Cafeteria sp. were 0.19 and $0.05 \mathrm{~d}^{-1}$, respectively. With increasing mean prey concentration, the ingestion rates of O. marina, G. cf. guttula, and P. piscicida on Cafeteria sp. rapidly increased at mean prey concentrations $<100 \mathrm{ng} \mathrm{ml}^{-1}$ (ca. 20000 cells ml ${ }^{-1}$ ), but slowly increased at higher mean prey concentrations. The maximum ingestion rate of $O$. marina on Cafeteria sp. (0.294 $\mathrm{ng} \mathrm{C}$ predator $\left.{ }^{-1} \mathrm{~d}^{-1}\right)$ was much higher than that of G. cf. guttula $\left(0.034 \mathrm{ng} \mathrm{C}\right.$ predator $\left.{ }^{-1} \mathrm{~d}^{-1}\right)$ or P. piscicida $\left(0.028 \mathrm{ng} \mathrm{C}\right.$ predator $\left.{ }^{-1} \mathrm{~d}^{-1}\right)$. The maximum clearance rates were 0.18 to $0.54 \mu$ predator $^{-1} \mathrm{~h}^{-1}$. Mean grazing coefficients for $O$. marina and G. cf. guttula on co-occurring HNFs calculated in the present study were 2.88 and $0.42 \mathrm{~d}^{-1}$, respectively. The results of the present study suggest that $O$. marina and G. cf. guttula sometimes have considerable grazing impacts on populations of HNFs.
\end{abstract}

KEY WORDS: Feeding $\cdot$ Food web $\cdot$ Growth $\cdot$ Ingestion $\cdot$ Protist $\cdot$ Protozoa

\section{INTRODUCTION}

Marine heterotrophic nanoflagellates (HNFs) are major components of marine planktonic food webs (e.g. Patterson \& Larsen 1991). They are major predators of marine bacteria and occasionally control the populations of marine bacteria (Fenchel 1982, Azam et al. 1983, Sieburth 1984) and, in turn, they are prey for ciliates (e.g. Verity 1991). Therefore, they are known to play an important role in the transfer of bacteria to ciliates in marine microbial loops. However, feeding by heterotrophic protists other than ciliates on HNFs is poorly understood as yet.

Heterotrophic dinoflagellates (HTDs) are often abundant and ubiquitous protists in marine environments (e.g. Jeong 1999). They have diverse ecological 
roles in marine planktonic communities (Lessard 1991, Jeong 1995, 1999, Sherr \& Sherr 2000, Tillmann \& Reckermann 2002); HTDs are known to feed on a diverse array of prey species, such as heterotrophic bacteria, phytoplankton, mixotrophic dinoflagellates (Hansen 1992, Strom \& Buskey 1993, Jeong \& Latz 1994, Jeong et al. 2004b, 2005a, 2006, Kim \& Jeong 2004, Tillmann 2004), heterotrophic protists, and metazoans through a variety of feeding mechanisms (Burkholder \& Glasgow 1995, Hansen \& Calado 1999, Jeong et al. 2005a). HTDs are also known to be important prey for several planktonic consumers such as ciliates (Jeong et al. 2004a) and copepods (Jeong et al. 2001a). They have also been found to participate in reciprocal predator-prey interactions with mixotrophic dinoflagellates (Jeong et al. 1997). Recently several HTD species such as Pfiesteria piscicida, Pseudopfiesteria shumwayae, Stoeckeria algicida, and Luciella masanensis (previously Lucy) have been newly discovered (Steidinger et al. 1996, Litaker et al. 2005, Jeong et al. 2005b, 2007, Mason et al. 2007). These heterotrophic dinoflagellates are harmful to finfish and shellfish due to their feeding on the blood cells and flesh of fish. Discovering new interactions among major components of marine plankton food webs is one of the most important steps in understanding the function of marine pelagic ecosystems. However, the feeding by HTDs on HNFs has not yet been explored, even though HTDs and HNFs often co-occur (e.g. Gonzalez et al. 1998).

To understand the interactions between HTDs and HNFs, we established monoclonal cultures of the HTDs Oxyrrhis marina, Gyrodinium cf. guttula, Pfiesteria piscicida, Luciella masanensis, and Stoeckeria algicida and the common HNF Cafeteria sp. and conducted a range of experiments. We (1) investigated whether or not the 5 HTDs, having a wide range of morphological properties (size, shape, thecate or naked, etc.) and feeding mechanisms, were able to feed on Cafeteria sp. and (2) measured the ingestion rates of $O$. marina, G. cf. guttula, and $P$. piscicida on the HNF as a function of the prey concentration. (3) The ingestion rates of HTDs on HNFs were compared to those of ciliates reported in the literature, and (4) they were also compared to HTDs on algal prey reported in the literature. (5) We also estimated the grazing coefficients attributable to $O$. marina and G. cf. guttula on co-occurring HNFs using our data for ingestion rates obtained from laboratory experiments and from the abundances of predators and prey in the field. The results of the present study provide a basis for understanding the interactions between HTDs and co-occurring HNFs and the potential for HTDs to influence the population dynamics of HNFs.

\section{MATERIALS AND METHODS}

Preparation of experimental organisms. For the isolation and culture of Cafeteria sp. (GenBank accession no. AM493687), plankton samples, collected with water samplers, were taken in Shiwha Bay, Korea, during October 2005, when the water temperature and salinity were $21.3^{\circ} \mathrm{C}$ and $24.5 \mathrm{psu}$, respectively. The samples were gently screened through a $5 \mu \mathrm{m}$ Nitex mesh and placed in $80 \mathrm{ml}$ polycarbonate (PC) bottles. Two barley seeds were added to each bottle to increase the abundance of bacteria that were potential prey for HNFs. The bottles were placed on plankton wheels rotating at $0.9 \mathrm{rpm}$ and incubated at $20^{\circ} \mathrm{C}$ in darkness. A week later, aliquots of the enriched water were transferred to 6-well tissue culture plates and a monoclonal culture of Cafeteria sp. was established by 3 serial, single-cell isolations. Once dense cultures of Cafeteria sp. were obtained, they were transferred to $270 \mathrm{ml}$ PC bottles of bacteria (density = ca. $10^{6}$ cells $\mathrm{ml}^{-1}$ ) and any aggregated materials were removed by screening every 3 d. Experiments were conducted when a large volume of Cafeteria sp. culture was available.

For the isolation and culture of Oxyrrhis marina, plankton samples, collected with a $25 \mathrm{~cm}$ diameter, $25 \mu \mathrm{m}$ mesh plankton net, were taken from the mouth of the Keum Estuary, Kunsan, Korea, during May 2001, when the water temperature and salinity were $16.0^{\circ} \mathrm{C}$ and $27.7 \mathrm{psu}$, respectively. A monoclonal culture was established by 2 serial single-cell isolations, as in Jeong et al. (2003).

For the isolation and culture of Gyrodinium cf. guttula, plankton samples, collected with water samplers, were taken from coastal waters off Masan, Korea, during April 2003, when the water temperature and salinity were $18.5^{\circ} \mathrm{C}$ and $25 \mathrm{psu}$, respectively. A monoclonal culture of $G$. cf. guttula was established by 2 serial, single-cell isolations.

For the isolation and culture of Pfiesteria piscicida, plankton samples, collected with water samplers, were taken from coastal waters off Incheon, Korea, during July 2005, when the water temperature and salinity were $24.0^{\circ} \mathrm{C}$ and $25.4 \mathrm{psu}$, respectively. A monoclonal culture of $P$. piscicida was established by 2 serial, single-cell isolations, as in Jeong et al. (2006).

For the isolation and culture of Stoeckeria algicida, plankton samples, collected with water samplers, were taken from a pier in Masan Bay, Korea, during July 2004, when the water temperature and salinity were $24.8^{\circ} \mathrm{C}$ and $20.6 \mathrm{psu}$, respectively. A monoclonal culture of $S$. algicida was established by 2 serial, singlecell isolations, as in Jeong et al. (2005a).

For the isolation and culture of Luciella masanensis, plankton samples, collected with water samplers, were 
taken from a pier in Masan Bay, Korea, during April 2005, when the water temperature and salinity were $16.0^{\circ} \mathrm{C}$ and $28.0 \mathrm{psu}$, respectively. A monoclonal culture of $L$. masanensis was established by 2 serial, single-cell isolations, as in Jeong et al. (2007).

The carbon contents for Cafeteria sp. (0.005 ng C cell $^{-1}, \mathrm{n}=30$ ) were estimated from cell volume according to Menden-Deuer \& Lessard (2000).

Feeding occurrence. These experiments were designed to test whether or not each of the HTDs Oxyrrhis marina, Gyrodinium cf. guttula, Pfiesteria piscicida, Luciella masanensis, and Stoeckeria algicida was able to feed on an HNF.

HNFs were fluorescently labeled using dichlorotriazinylaminofluorescein (DTAF) (fluorescently labeled HNF [FLH]; Sherr et al. 1987). Approximately $8 \times$ $10^{6} \mathrm{FLH}$ cells were added into each of two $80 \mathrm{ml}$ PC bottles containing each HTD at 1000 cells ml${ }^{-1}$. One control bottle (without FLH) was set up for each experiment. The bottles were placed on a plankton wheel rotating at $0.9 \mathrm{rpm}$ and incubated at $20^{\circ} \mathrm{C}$ under an illumination of $20 \mu \mathrm{E} \mathrm{m}^{-2} \mathrm{~s}^{-1}$ of cool white fluorescent light, on a $14 \mathrm{~h}$ light:10 h dark cycle.

After $30 \mathrm{~min}$ and 1, 6, and $24 \mathrm{~h}$ incubation, $5 \mathrm{ml}$ aliquots were removed from each bottle, transferred into $20 \mathrm{ml}$ vials, and then fixed with borate-buffered formalin (final conc. $=4 \%$ ). The fixed samples were stained using DAPI (final conc. $=1 \mu \mathrm{M}$ ) and then filtered onto PC white membrane filters with a $5 \mu \mathrm{m}$ pore size. Approximately 300 to 1000 concentrated cells on the membranes were observed using epifluorescence microscopy at a magnification of $1250 \times$, and pictures were taken.

Growth and ingestion rates. These experiments were designed to measure growth, ingestion, and clearance rates of Oxyrrhis marina, Gyrodinium cf. guttula, and Pfiesteria piscicida, respectively, as functions of prey concentration, when feeding on Cafeteria sp.

One day before these experiments were conducted, a dense culture of Oxyrrhis marina (ca. 8000 cells ml $^{-1}$ ) growing on the raphidophyte Heterosigma akashiwo (ca. 30000 cells ml$^{-1}$ ) was transferred into $270 \mathrm{ml} \mathrm{PC}$ bottles containing a low (5000 cells ml-1) and a medium HNF concentration (15000 cells $\mathrm{ml}^{-1}$ ) of the target prey. This was done to acclimatize the predator to the target prey and to minimize possible residual growth resulting from ingestion of prey during batch culture. The bottles were filled to capacity with filtered seawater and placed on a rotating wheel to incubate as above. The abundances of $O$. marina and the prey were determined by enumerating cells in three $1 \mathrm{ml}$ Sedgwick-Rafter counting chambers (hereafter SRCs).

The initial concentrations of Oxyrrhis marina and the HNF were established using an autopipette to deliver predetermined volumes of known cell concentrations to the bottles. Triplicate $80 \mathrm{ml}$ PC experiment bottles (mixtures of predator and prey), triplicate prey control bottles (prey only), and triplicate predator control bottles (predator only) were set up for each predator-prey combination. To make the water conditions similar, some water from a predator culture was filtered through a GF/F filter (pore size $=0.7 \mu \mathrm{m}$ ) and then added into the prey control bottles in the same amount as the volume of the predator culture added into the predator control bottles and the experimental bottles for each predator-prey combination. Also, some water from a prey culture was filtered through a GF/F filter (pore size $=0.7 \mu \mathrm{m}$ ) and then added into the predator control bottles in the same amount as the volume of the prey culture added into the prey control bottles and the experimental bottles. Ten $\mathrm{ml}$ of $f / 2$ medium were added to all bottles, which were then filled to capacity with freshly filtered seawater and capped. To determine the actual predator and prey densities $\left(\right.$ cells ml$\left.{ }^{-1}\right)$ at the beginning of the experiment (O. marina/ Cafeteria sp. $=6 / 26,17 / 59,26 / 173,41 / 609,79 / 3730,187 /$ 17 050, 236/44 690, 478/78 080; Gyrodinium cf. guttula/ Cafeteria sp. $=14 / 48,40 / 153,74 / 666,103 / 1130,274 /$ 4480, 459/11 120，672/41050, 713/67 210; Pfiesteria piscicida/Cafeteria sp. $=20 / 46,66 / 145,111 / 412,271 /$ 943，356/8300, 664/20 430, 862/42 980，1537/63630) and after $48 \mathrm{~h}$ incubation, a $3 \mathrm{ml}$ aliquot for enumerating predator cells was removed from each bottle and fixed with $5 \%$ Lugol's solution, and a $7 \mathrm{ml}$ aliquot for enumerating prey cells was removed from each bottle and fixed with $4 \%$ formalin. All (low predator concentration) or $>300$ (high predator concentrations) predator cells in the samples fixed with $5 \%$ Lugol's solution in two $1 \mathrm{ml}$ SRCs were enumerated under a compound microscope. DAPI was added to the samples fixed with $4 \%$ formalin, which were then filtered by a $0.8 \mu \mathrm{m}$ black PC membrane filter. Almost all or $>300$ prey cells on the filters were enumerated using epifluorescence microscopy. The bottles were filled again to capacity with freshly filtered seawater, capped, and placed on rotating wheels under the same environmental conditions as described above. Dilution of the cultures associated with refilling the bottles was considered in calculating growth and ingestion rates. The experiments for Gyrodinium cf. guttula and Pfiesteria piscicida were also conducted as described above after $G$. cf. guttula and $P$. piscicida were acclimated for $1 \mathrm{~d}$ as was done with $O$. marina.

The specific growth rate of a HTD, $\mu\left(\mathrm{d}^{-1}\right)$, was calculated as follows:

$$
\mu=\frac{\ln \left(L_{t} / L_{0}\right)}{t}
$$

where $L_{0}$ is the initial concentration of the HTD; $t$ is time in $\mathrm{d}_{i}$ and $L_{t}$ is the final concentration after $2 \mathrm{~d}$. 
Data for the growth rate of Oxyrrhis marina were fitted to a Michaelis-Menten equation:

$$
\mu=\frac{\mu_{\max }\left(x-x^{\prime}\right)}{K_{\mathrm{GR}}+\left(x-x^{\prime}\right)}
$$

where $\mu_{\max }$ is the maximum growth rate $\left(\mathrm{d}^{-1}\right), x$ is the prey concentration (cells $\mathrm{ml}^{-1}$ or $\mathrm{ng} \mathrm{C} \mathrm{ml} \mathrm{C}^{-1}$ ), $\mathrm{x}^{\prime}$ is the threshold prey concentration (the prey concentration where $\mu=0$ ), and $K_{\mathrm{GR}}$ is the prey concentration sustaining $1 / 2 \mu_{\text {max }}$. Data were iteratively fitted to the model using DeltaGraph (Delta Point).

Ingestion and clearance rates were calculated using the equations by Frost (1972) and Heinbokel (1978). The incubation time for calculating ingestion and clearance rates was the same as for estimating the growth rate. Ingestion rate data for a HTD were fitted to a Michaelis-Menten equation:

$$
\mathrm{IR}=\frac{I_{\max }(x)}{K_{\mathrm{IR}}+(x)}
$$

where $I_{\max }$ is the maximum ingestion rate (cells predator $^{-1} \mathrm{~d}^{-1}$ or ng $\mathrm{C}$ predator ${ }^{-1} \mathrm{~d}^{-1}$ ), $\mathrm{x}$ is the prey concentration (cells ml ${ }^{-1}$ or $\mathrm{ng} \mathrm{C} \mathrm{ml}^{-1}$ ), and $K_{\mathrm{IR}}$ is the prey concentration sustaining $1 / 2 I_{\max }$.

Grazing impact. We estimated the grazing coefficients attributable to Oxyrrhis marina and Gyrodinium cf. guttula on HNFs by combining field data on the abundances of O. marina and G. cf. guttula and their prey with ingestion rates of the predators on Cafeteria sp. obtained in the present study. The data on the abundances of $O$. marina and HNFs ( 2 to $5 \mu \mathrm{m}$ in size) used in this estimation were obtained from water samples collected from solar salterns near Shiwha, Korea (in 2006), while those for $G$. cf. guttula (plus G. dominans) and HNFs (2 to $5 \mu \mathrm{m}$ in size) were obtained from the water samples taken in Masan Bay, Korea (in 2004 and 2005). For this estimation, we assumed that the ingestion rates of $O$. marina and G. cf. guttula on the HNFs (2 to $5 \mu \mathrm{m}$ in size) were the same as those on Cafeteria sp. and that the ingestion rate of G. dominans was the same as that of $G$. cf. guttula.

The grazing coefficients $\left(g, \mathrm{~d}^{-1}\right)$ were calculated as:

$$
g=\mathrm{CR} \times \mathrm{PC} \times 24
$$

where CR (ml HTD ${ }^{-1} \mathrm{~h}^{-1}$ ) is the clearance rate of an HTD on HNF at a particular prey concentration and PC is the predator concentration (cells ml-1). CRs were calculated as:

$$
\mathrm{CR}=\mathrm{IR} / x
$$

where IR (cells eaten $\mathrm{HTD}^{-1} \mathrm{~h}^{-1}$ ) is the ingestion rate of the predator on the prey and $x\left(\right.$ cells $\mathrm{ml}^{-1}$ ) is the prey concentration. CRs were corrected using $Q_{10}=2.8$ (Hansen et al. 1997), because in situ water temperatures and the temperature used in the laboratory for this experiment $\left(20^{\circ} \mathrm{C}\right)$ were sometimes different.

\section{RESULTS}

\section{HTD predators}

Among the 5 HTDs tested, Oxyrrhis marina, Gyrodinium cf. guttula, Luciella masanensis, and Pfiesteria piscicida were able to ingest Cafeteria sp. (Fig. 1), but Stoeckeria algicida did not feed on the HNF. Up to $7 \mathrm{HNF}$ cells were observed inside the protoplasm of O. marina.

\section{Growth rates}

Cafeteria sp. supported positive growth in Oxyrrhis marina and Gyrodinium cf. guttula, but not in Pfiesteria piscicida (Figs. 2 to 4 ).

Specific growth rates of Oxyrrhis marina on Cafeteria sp. increased with increasing mean prey concentration before becoming saturated at the mean prey concentration of ca. $100 \mathrm{ng} \mathrm{C} \mathrm{ml}^{-1}$ (20000 cells ml ${ }^{-1}$; Fig. 2). The maximum specific growth rate of $O$. marina on Cafeteria sp. was $0.19 \mathrm{~d}^{-1}$ when the data were fitted to Eq. (2). The threshold prey concentration (where net growth = 0 ) for $O$. marina was $0.059 \mathrm{ng} \mathrm{C} \mathrm{ml}^{-1}\left(12 \mathrm{cells} \mathrm{ml}^{-1}\right)$.
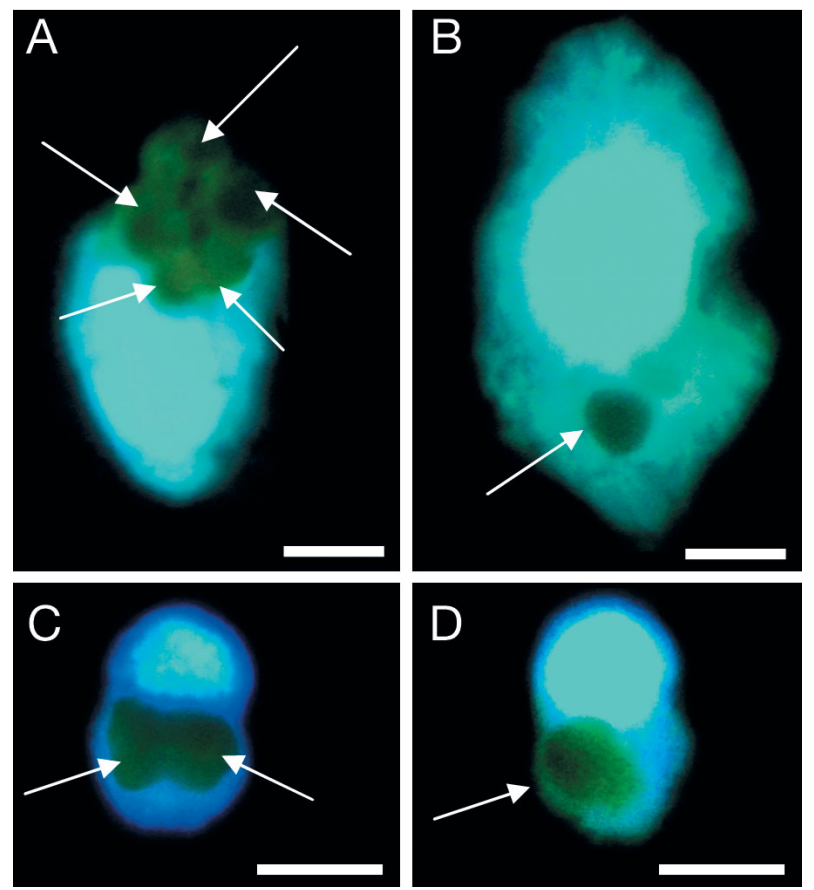

Fig. 1. Feeding by heterotrophic dinoflagellates on the heterotrophic nanoflagellate (HNF) Cafeteria sp. (A) Oxyrrhis marina with 5 ingested HNFs, (B) Gyrodinium cf. guttula with an ingested HNF, (C) Pfiesteria piscicida with 2 ingested HNFs, and (D) Luciella masanensis with an ingested HNF. Scale bars: $5 \mu \mathrm{m}$. Arrows indicate ingested prey cells, which are fluorescently labeled HNFs. All photographs were taken using epifluorescence microscopy 


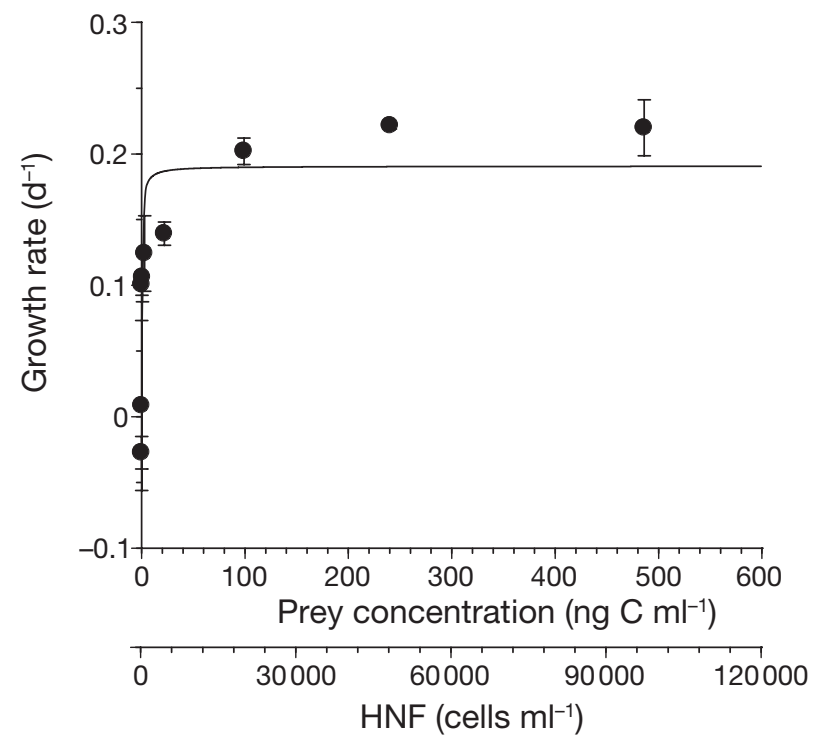

Fig. 2. Oxyrrhis marina. Specific growth rates of heterotrophic dinoflagellate (HTD) O. marina on heterotrophic nanoflagellate (HNF) Cafeteria sp. as a function of mean prey concentration $(x)$. Symbols represent treatment means $( \pm 1 \mathrm{SE})$. The curve is fitted by a Michaelis-Menten equation (Eq. 2) using all treatments in the experiment. Growth rate $\left(G R, d^{-1}\right)=0.19$ $\{(x-0.059) /[0.48+(x-0.059)]\}, r^{2}=0.744$

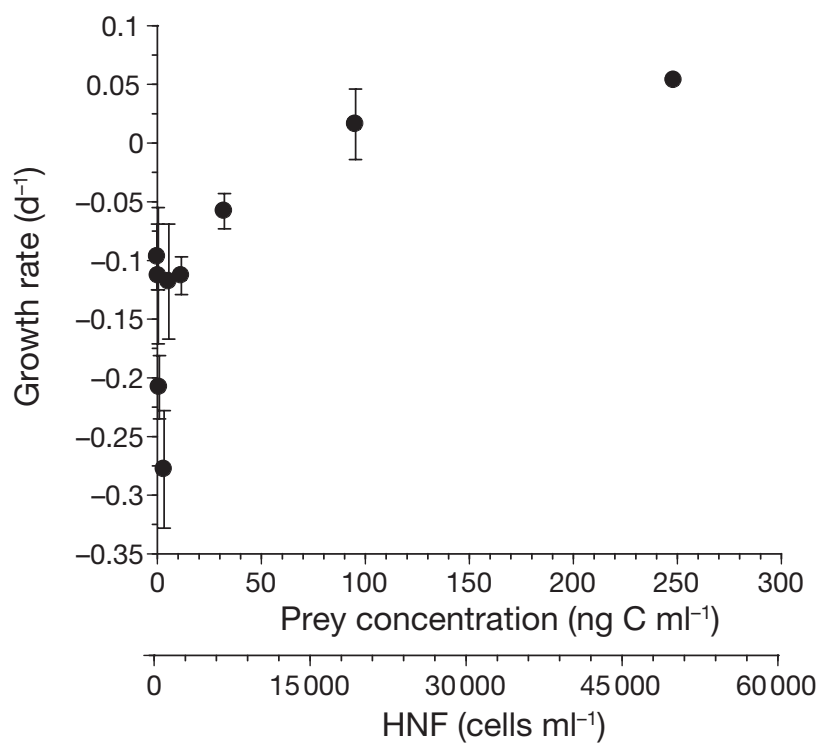

Fig. 3. Gyrodinium cf. guttula. Specific growth rates of $G$. cf. guttula (HTD) on Cafeteria sp. (HNF) as a function of mean prey concentration $(x)$. Symbols represent treatment means $( \pm 1 \mathrm{SE})$

Specific growth rates of Gyrodinium cf. guttula on Cafeteria sp. increased with increasing mean prey concentration before saturating at the mean prey concentration of ca. $100 \mathrm{ng} \mathrm{C} \mathrm{ml}{ }^{-1}$ (20000 cells ml ${ }^{-1}$; Fig. 3). At the given prey concentrations, the observed maximum growth rate of $G$. cf. guttula on Cafeteria sp. was $0.054 \mathrm{~d}^{-1}$.

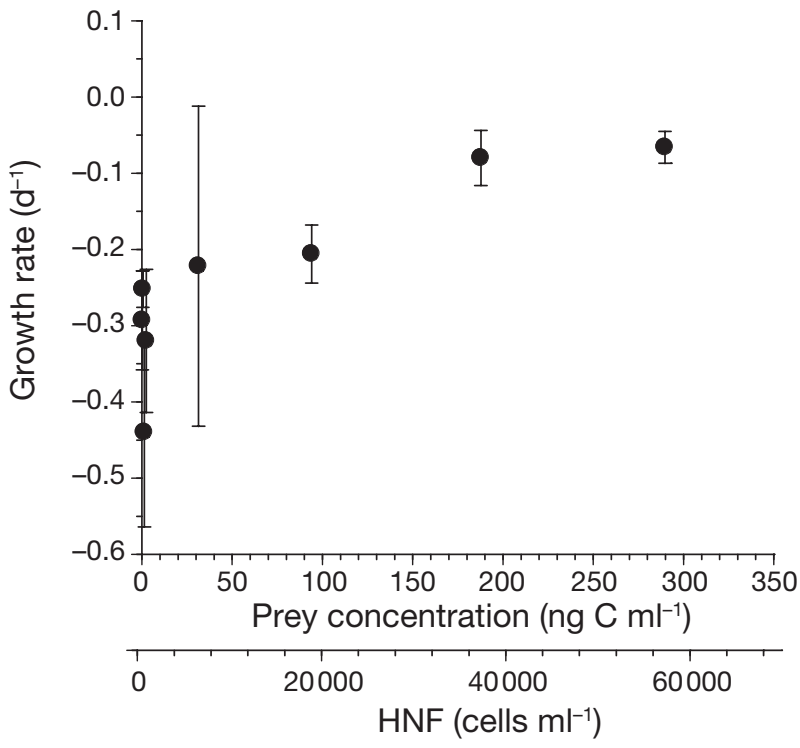

Fig. 4. Pfiesteria piscicida. Specific growth rates of $P$. piscicida (HTD) on Cafeteria sp. (HNF) as a function of mean prey concentration $(x)$. Symbols represent treatment means $( \pm 1$ SE)

Specific growth rates of Pfiesteria piscicida on Cafeteria sp. increased with increasing mean prey concentration. At the given prey concentrations, the observed maximum specific growth rate of $P$. piscicida on Cafeteria sp. was $-0.08 \mathrm{~d}^{-1}$ (Fig. 4).

\section{Ingestion and clearance rates}

With increasing mean prey concentration, the ingestion rates of Oxyrrhis marina, Gyrodinium cf. guttula, and Pfiesteria piscicida on Cafeteria sp. rapidly increased at mean prey concentrations $<100 \mathrm{ng} \mathrm{ml}^{-1}$ (ca. 20000 cells ml$^{-1}$ ), but slowly increased at higher mean prey concentrations (Figs. 5 to 7 ). The maximum ingestion rates (cells predator ${ }^{-1} \mathrm{~d}^{-1}$ in parentheses) of O. marina, G. cf. guttula, and $P$. piscicida on Cafeteria sp. were 0.294 (59), 0.034 (7), and 0.028 (6) ng C predator ${ }^{-1}$ $\mathrm{d}^{-1}$, respectively, when the data were fitted to Eq. (3). Gross growth efficiencies, defined as predator biomass produced or lost per prey biomass ingested, where the maximum growth and ingestion rates were obtained, were $23 \%$ for $O$. marina and $41 \%$ for $G$. cf. guttula.

The maximum clearance rates of HTDs on Cafeteria sp. were $0.54 \mu \mathrm{l}$ predator $^{-1} \mathrm{~h}^{-1}$ for Oxyrrhis marina, $0.18 \mu \mathrm{l}$ predator ${ }^{-1} \mathrm{~h}^{-1}$ for Gyrodinium cf. guttula, and $0.39 \mu \mathrm{l}$ predator $^{-1} \mathrm{~h}^{-1}$ for Pfiesteria piscicida.

\section{Grazing impact}

When the abundances of Oxyrrhis marina and HNFs $(\mathrm{n}=19)$ in the high-salinity waters (salinity $=36.2$ to 


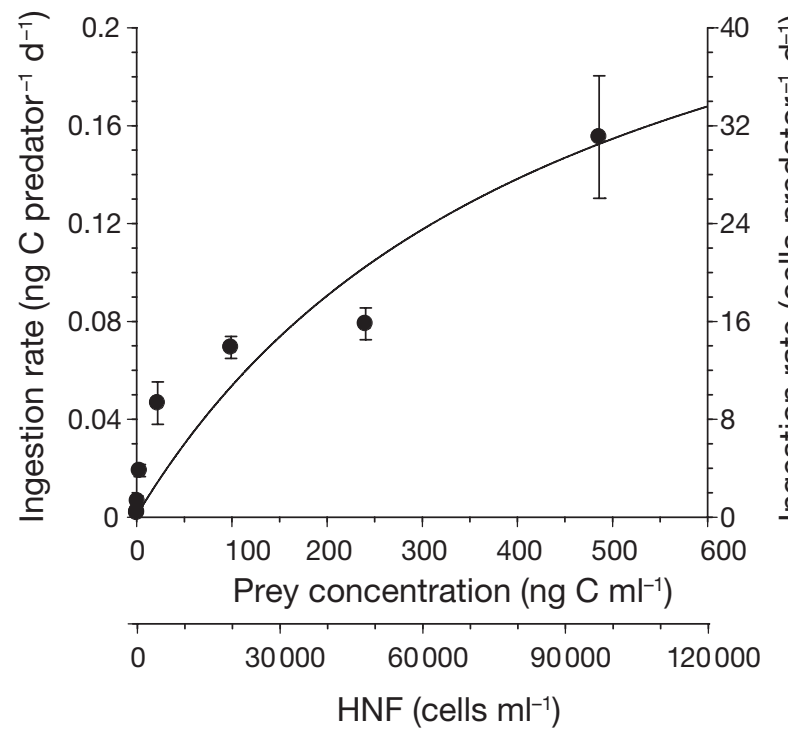

Fig. 5. Oxyrrhis marina. Ingestion rates of O. marina (HTD) on Cafeteria sp. (HNF) as a function of mean prey concentration $(x)$. Symbols represent treatment means $( \pm 1 \mathrm{SE})$. The curve is fitted by a Michaelis-Menten equation (Eq. 3) using all treatments in the experiment. Ingestion rate (IR, ng $\mathrm{C}$ grazer $^{-1}$ $\left.\mathrm{d}^{-1}\right)=0.294[\mathrm{x} /(455+\mathrm{x})], \mathrm{r}^{2}=0.874$

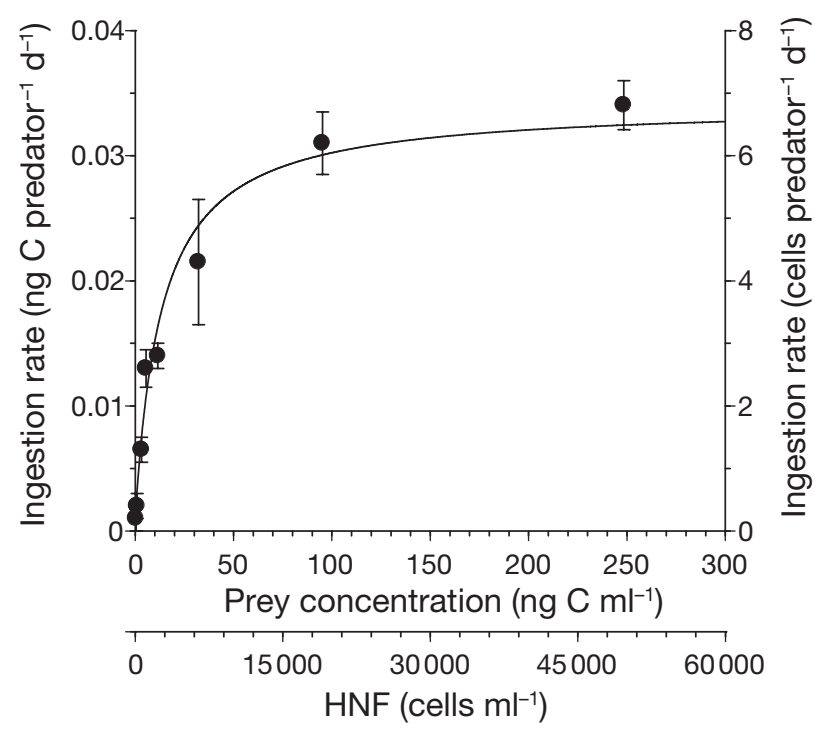

Fig. 6. Gyrodinium cf. guttula. Ingestion rates of G. cf. guttula (HTD) on Cafeteria sp. (HNF) as a function of mean prey concentration $(x)$. Symbols represent treatment means $( \pm 1 \mathrm{SE})$. The curve is fitted by a Michaelis-Menten equation (Eq. 3) using all treatments in the experiment. Ingestion rate (IR, ng C grazer $\left.{ }^{-1} \mathrm{~d}^{-1}\right)=0.034[\mathrm{x} /(13+\mathrm{x})], \mathrm{r}^{2}=0.877$

$101 \mathrm{psu}$, mean $\pm \mathrm{SE}=50.2 \pm 3.5 \mathrm{psu}$ ) of solar salterns near Shiwha in 2006 were 1 to 6130 cells ml ${ }^{-1}$ (mean \pm $\mathrm{SE}=2160 \pm 420 \mathrm{cells} \mathrm{ml}^{-1}$ ) and 1900 to $7080 \mathrm{cells} \mathrm{ml}^{-1}$ $\left(4570 \pm 330\right.$ cells $\left.\mathrm{ml}^{-1}\right)$, respectively, the grazing coefficients attributable to $O$. marina on co-occurring HNFs

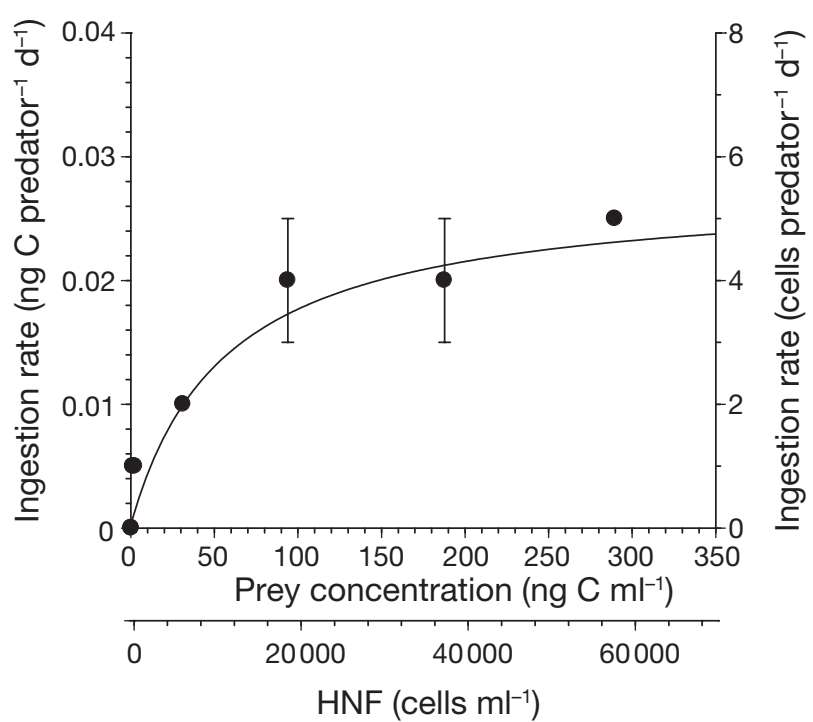

Fig. 7. Pfiesteria piscicida. Ingestion rates of $P$. piscicida (HTD) on Cafeteria sp. (HNF) as a function of mean prey concentration $(x)$. Symbols represent treatment means $( \pm 1 \mathrm{SE})$. The curve is fitted by a Michaelis-Menten equation (Eq. 3) using all treatments in the experiment. Ingestion rate (IR, ng C grazer $\left.{ }^{-1} \mathrm{~d}^{-1}\right)=0.028[x /(56+x)], \mathrm{r}^{2}=0.886$

were 0.06 to $8.25 \mathrm{~d}^{-1}$ (mean $\pm \mathrm{SE}=2.88 \pm 0.58 \mathrm{~d}^{-1}$; Fig. 8A). In general, grazing coefficients increased with increasing $O$. marina concentration.

When the abundances of Gyrodinium cf. guttula (plus G. dominans) and HNFs ( $=27)$ in Masan Bay in 2004 and 2005 were 25 to 750 cells ml $^{-1}$ (mean $\pm \mathrm{SE}=$ $159 \pm 37$ cells $\left.\mathrm{ml}^{-1}\right)$ and 66 to 1840 cells $\mathrm{ml}^{-1}(498 \pm$ 82 cells $\mathrm{ml}^{-1}$ ), respectively, the grazing coefficients attributable to G. cf. guttula on co-occurring HNFs were 0.02 to $2.17 \mathrm{~d}^{-1}$ (mean $\pm \mathrm{SE}=0.42 \pm 0.11 \mathrm{~d}^{-1}$; Fig. 8B). In general, grazing coefficients also increased with increasing G. cf. guttula concentration.

\section{DISCUSSION}

\section{Predators on HNF}

The present study shows that several HTD species (Oxyrrhis marina, Gyrodinium cf. guttula, Luciella masanensis, and Pfiesteria piscicida) are able to ingest the tested species of HNF. Before the present study, ciliates, rotifers, copepods, and cladocerans had been reported to ingest HNFs in aquatic ecosystems (Turner et al. 1988, Verity 1991, Sanders et al. 1994, Jürgens et al. 1996). Therefore, this is the first study reporting the feeding by HTDs on HNFs in aquatic ecosystems. These predatorprey relationships between HNFs and HTDs may influence our conventional view of energy flow and carbon cycling in the marine planktonic community. 

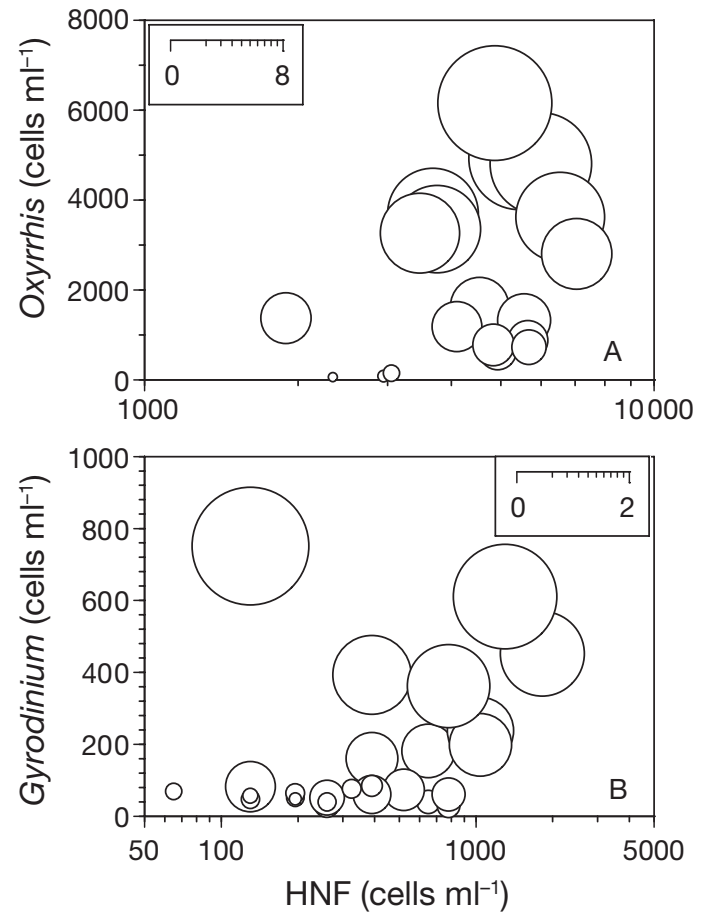

Fig. 8. Calculated grazing coefficients $\left(g, \mathrm{~d}^{-1}\right.$, see scale bars) attributable to Oxyrrhis marina (A) and Gyrodinium cf. guttula (B) on HNFs (see 'Materials and methods' for calculation); $\mathrm{n}=19$ for $O$. marina and $\mathrm{n}=27$ for $G$. cf. guttula

HNFs and small ciliates are known to be one of the major predators on bacteria (Fenchel 1982, Azam et al. 1983, Sieburth 1984, Vaque et al. 2002). Recently, it has been shown that red-tide dinoflagellates and raphidophytes also feed on marine autotrophic and heterotrophic bacteria and have considerable grazing impact on the prey populations (Jeong et al. 2005c, Seong et al. 2006). Therefore, based on the results of this study and the literature, 4 possible major pathways from bacteria to ciliates in marine planktonic communities can be established: (1) bacteria-red-tide algae-HTDs-large ciliates (Jeong et al. 2001b, 2003, 2004a, 2005c, Seong et al. 2006); (2) bacteria-HNFs-HTDs-large ciliates (Vaque et al. 2002, Jeong et al. 2004a, present study); (3) bacteria-HNFs-ciliates (Verity 1991, Šolić \& Krstulović 1994); and (4) bacteria-ciliates (Sherr et al. 1989, Seong et al. 2006). Discovery of the feeding by HTDs on HNFs increases our knowledge of the complexity of marine microbial food webs. HTDs are sometimes likely to compete with some ciliates for HNF prey in marine planktonic communities.

While Pfiesteria piscicida fed on Cafeteria sp., the Pfiesteria-like dinoflagellate (PLD) Stoeckeria algicida did not ingest the HNF. S. algicida was revealed to only feed on the raphidophyte Heterosigma akashiwo and fish blood cells, while $P$. piscicida fed on diverse species of dinoflagellates, raphidophytes, and cryptophytes, as well as on fish blood cells (Jeong et al. 2006). The results of the present study confirm that these 2 HTDs have different responses to prey species, even though their size, shape, and feeding mechanisms are very similar. Therefore, $P$. piscicida and some PLDs may have different ecological niches in marine ecosystems.

\section{Growth and ingestion}

Cafeteria sp. supported the positive growth of Oxyrrhis marina and Gyrodinium cf. guttula, while it did not support that of Pfiesteria piscicida. The maximum growth rate (MGR) of $O$. marina on Cafeteria sp. $\left(0.19 \mathrm{~d}^{-1}\right)$ was higher than that of $G$. cf. guttula $\left(0.05 \mathrm{~d}^{-1}\right)$ or $P$. piscicida $\left(-0.08 \mathrm{~d}^{-1}\right)$. The higher maximum ingestion rate (MIR) of $O$. marina $\left(0.29 \mathrm{ng} \mathrm{C}\right.$ predator $\left.{ }^{-1} \mathrm{~d}^{-1}\right)$ seemed to be responsible for this higher MGR compared to that of G. cf. guttula (0.034 ng C predator ${ }^{-1} \mathrm{~d}^{-1}$ ) or of $P$. piscicida (0.028 ng C predator ${ }^{-1} \mathrm{~d}^{-1}$ ). Deploying a tow filament and then engulfing a swimming HNF cell (O. marina) may be a more efficient feeding mechanism than directly engulfing the prey cell (G. cf. guttula) or sucking materials from the prey using a peduncle $(P$. piscicida). In natural environments, $O$. marina is expected to be one of the most abundant HTDs when HNFs are abundant, but alternative prey is rare. However, G. cf. guttula and P. piscicida do not seem to be abundant under these circumstances.

There had been only a single study reporting the growth and/or ingestion rates of marine protistan predators on HNFs before the present study (Verity 1991). MGR of Oxyrrhis marina on Cafeteria sp. is considerably lower than that of the naked ciliate Strobilidium spiralis $\left(0.49 \mathrm{~d}^{-1}\right.$; Table 1$)$. MIR of $S$. spiralis on Cafeteria sp. (1.1 ng C predator ${ }^{-1} \mathrm{~d}^{-1}$ ) is also 3 to 4 times higher than that of $O$. marina. The much larger size of $S$. spiralis may be responsible for its higher MIR compared to that of O. marina. Based on this comparison of MGRs, the abundance of $O$. marina is expected to be lower than that of $S$. spiralis when Cafeteria sp. is abundant and alternative prey is rare.

MGR and MIR of Oxyrrhis marina on Cafeteria sp. ( $0.19 \mathrm{~d}^{-1}$ and $0.29 \mathrm{ng} \mathrm{C}$ predator ${ }^{-1} \mathrm{~d}^{-1}$, respectively) are much lower than those of $O$. marina on the raphidophytes Heterosigma akashiwo and Fibrocapsa japonica, the dinoflagellate Amphidinium carterae, or the diatom Phaeodactylum tricornutum $\left(0.7\right.$ to $1.4 \mathrm{~d}^{-1}$ and 1.3 to 7.0 ng C predator ${ }^{-1} \mathrm{~d}^{-1}$; Table 2). Therefore, for O. marina, the algae may be better prey than HNFs and thus HNFs are likely to be supplementary prey when both the algal prey and HNFs are abundant. However, when the abundance of the algal prey is low, but that of HNFs is high, HNFs may be a major prey item. Data from studies on the feeding of $O$. marina on the HNF and algal prey 
listed in Table 2 suggest that either the MGR or MIR of $O$. marina on the 7 different prey species does not correlate significantly with prey size (equipment spherical diameter, ESD) ( $p>0.1$, linear regression ANOVA). This relationship suggests that the sizes of prey may not be a critical factor affecting the growth and ingestion rates of O. marina. Strobilidium spiralis is known to ingest less Cafeteria sp. than Isochrysis galbana as well (Verity 1991). Therefore, Cafeteria sp. may be a less preferred prey for HTDs and ciliates compared to the algal prey. The C:N ratio of $I$. galbana (6.7) is slightly lower than that of Cafeteria sp. (7.1; Verity 1991), and thus their nutritional values may be similar. In our preliminary test, the mean $( \pm \mathrm{SE}, \mathrm{n}=30)$ swimming speed of Cafeteria sp. (106 $\pm 3 \mu \mathrm{m} \mathrm{s}^{-1}$ ) measured at $20^{\circ} \mathrm{C}$ was twice that of $I$. galbana $\left(47 \pm 3 \mu \mathrm{m} \mathrm{s}^{-1}\right)$. O. marina may have more difficulty in capturing, handling, and ingesting faster swimming Cafeteria cells than slower swimming I. galbana cells.

\section{Grazing impact}

In the waters of the solar salterns near Shiwha in 2006, $73 \%$ (mean) of co-occurring HNF populations were removed by Oxyrrhis marina populations in $1 \mathrm{~d}$. Also, in Masan Bay in 2004 and 2005, 34 \% (mean) of HNF populations was removed by Gyrodinium cf. guttula (plus G. dominans) populations in $1 \mathrm{~d}$. Therefore, the results of the present study suggest that $O$. marina and G. cf. guttula (plus G. dominans) can have a considerable grazing impact on populations of HNFs. Also, the grazing pressure by HTDs on bacterivorous HNFs may affect the population dynamics of marine bacteria, as HNFs occasionally control the populations of marine bacteria (Fenchel 1982, Sieburth 1984). There have been few studies reporting the grazing impact of marine ciliates on HNFs (Šolić \& Krstulović 1994); ciliates have been reported to remove 20 to $130 \%$ (mean = $57 \%$ ) of HNF standing stock in a day in the coastal Adriatic Sea. Thus, the grazing impact of HTDs may sometimes be comparable to that by ciliates. However, Cafeteria sp. was the less preferred prey for Strobilidium spiralis when a mixture of the photosynthetic nanoplankton Isochrysis galbana and Cafeteria sp. was provided as prey (Verity 1991). Therefore, the grazing coefficients attributable to $O$. marina on co-occurring HNFs and those attributable to $G$. cf. guttula might be overestimated if preferred algal prey co-existed.
Table 1. Comparison of growth, ingestion, and clearance rates of heterotrophic protists on the marine heterotrophic nanoflagellates Cafeteria sp. $(3.5 \mu \mathrm{m}$ in size) measured at $20^{\circ} \mathrm{C}$. PDC: predators' carbon $\left(\mathrm{ng} \mathrm{C}\right.$ cell $\left.{ }^{-1}\right) ; \mu_{\max }$ : maximum growth rate $\left(\mathrm{d}^{-1}\right) ; I_{\max }$ : maximum ingestion rate $\left(\mathrm{ng} \mathrm{C}\right.$ predator $\left.{ }^{-1} \mathrm{~d}^{-1}\right) ; C_{\max }$ : maximum clearance rate $\left(\mu \mathrm{l}\right.$ predator $\left.{ }^{-1} \mathrm{~h}^{-1}\right)$; HTD: heterotrophic dinoflagellate; NC: naked ciliate; TC: tintinnid ciliate

\begin{tabular}{|lccccccc|}
\hline Predator & & PDC & $\mu_{\max }$ & $I_{\max }$ & $C_{\max }$ & Source \\
\hline Pfiesteria piscicida & (HTD) & 0.05 & -0.08 & 0.028 & 0.39 & Present study \\
Oxyrrhis marina & (HTD) & 0.14 & 0.19 & 0.294 & 0.54 & Present study \\
Gyrodinium cf. guttula & (HTD) & 0.35 & 0.05 & 0.034 & 0.18 & Present study \\
Strobilidium cf. spiralis & (NC) & 3.5 & $0.49^{\mathrm{a}}$ & $1.1^{\mathrm{a}}$ & & Verity (1991) \\
Tintinnopsis dadayi & (TC) & 15 & $0.28^{\mathrm{a}}$ & & & Verity (1991) \\
& & & & & \\
a Obtained at mean prey concentrations of 250 to $260 \mathrm{ng} \mathrm{C} \mathrm{ml}^{-1}$ & \\
\hline
\end{tabular}

\section{Ecological importance}

The feeding of HTDs on HNFs may be important in marine planktonic communities in the following ways: (1) HTDs are another important protistan predator on HNFs. In general ciliates grow fast when suitable prey is abundant, but die quickly during periods of starvation (Jeong et al. 1999). However, HTDs can survive much longer than ciliates during periods of starvation (Jeong \& Latz 1994). Therefore, the pathway from bacteria to HTDs via HNFs may work more frequently in

Table 2. Oxyrrhis marina. Comparison of growth, ingestion, and clearance rates of $O$. marina on diverse protistan prey. Rates were corrected to $20^{\circ} \mathrm{C}$ using $Q_{10}=2.8$ (Hansen et al. 1997). ESD: equivalent spherical diameter $(\mu \mathrm{m}) ; \mu_{\text {max }}$ : maximum growth rate $\left(\mathrm{d}^{-1}\right) ; I_{\max }$ : maximum ingestion rate $\left(\mathrm{ng} \mathrm{C}\right.$ predator $\left.{ }^{-1} \mathrm{~d}^{-1}\right) ; C_{\max }$ : maximum clearance rate $\left(\mu l\right.$ predator $\left.{ }^{-1} \mathrm{~h}^{-1}\right) ; \mathrm{HNF}$ : heterotrophic nanoflagellate; DIA: diatom; PRY: prymnesiophyte; CHL: chlorophyte; MTD: mixotrophic dinoflagellate; RAP: raphidophyte

\begin{tabular}{|lcccccl|}
\hline Prey & & ESD & $\mu_{\max }$ & $I_{\max }$ & $C_{\max }$ & Source \\
\hline Cafeteria sp. & (HNF) & 3.5 & 0.19 & 0.3 & 0.53 & Present study \\
Phaeodactylum tricornutum & (DIA) & 4.2 & 1.30 & 2.6 & 0.002 & Goldman et al. (1989) \\
Isochrysis galbana & (PRY) & 4.8 & 0.79 & 7.0 & 0.02 & Goldman et al. (1989) \\
Dunaliella tertiolecta & (CHL) & 7.3 & 0.79 & 1.4 & 0.01 & Goldman et al. (1989) \\
Amphidinium carterae & (MTD) & 9.7 & 1.17 & 2.8 & 2.35 & Jeong et al. (2001a) \\
Heterosigma akashiwo & (RAP) & 11.5 & 1.43 & 1.3 & 0.29 & Jeong et al. (2003) \\
Fibrocapsa japonica & (RAP) & 20.3 & 1.20 & 2.0 & & Tillmann \& Reckermann (2002) \\
\hline
\end{tabular}


comparison to a pathway from bacteria to ciliates via HNFs. (2) HNFs support the growth of some HTDs, but do not support that of other HTDs. Therefore, HNFs may play an important role in determining dominant HTD species when HNFs are abundant, and alternative prey is rare. (3) In the present study, large portions of HNFs in Korean waters were removed by HTDs in a single day, and thus some HTDs are sometimes likely to control the populations of HNFs. Therefore, HTDs should be taken into consideration as an important factor affecting the population dynamics of HNFs. To understand interactions and transfer of materials and energy among bacteria, HNFs, HTDs, ciliates, and metazooplankton in marine planktonic food webs better, it would be worthwhile to explore the contribution in terms of predation pressure of co-occurring HTDs, ciliates, and metazooplankton on HNFs.

Acknowledgements. We thank Shin Kim, Kyeong A. Seong, Jong Hyeok Kim for technical support. This paper was funded by a NRL grant from MOST \& KOSEF (M1-0302-00-0068) and the RIC program from ITEP.

\section{LITERATURE CITED}

Azam F, Fenchel T, Field JG, Gray JS, Meyer-Reil LA, Thingstad F (1983) The ecological role of water-column microbes in the sea. Mar Ecol Prog Ser 10:257-263

Burkholder JM, Glasgow HB Jr (1995) Interactions of a toxic estuarine dinoflagellate with microbial predators and prey. Arch Protistenk 145:177-188

Fenchel T (1982) Ecology of heterotrophic microflagellates. IV. Quantitative occurrence and importance as bacterial consumers. Mar Ecol Prog Ser 9:35-42

Frost BW (1972) Effects of size and concentration of food particles on the feeding behavior of the marine planktonic copepod Calanus pacificus. Limnol Oceanogr 17:805-815

Goldman JC, Dennett MR, Gordin H (1989) Dynamics of herbivorous grazing by the heterotrophic dinoflagellate Oxyrrhis marina. J Plankton Res 11:391-407

Gonzalez JM, Torreton JP, Dufour P, Charpy L (1998) Temporal and spatial dynamics of the pelagic microbial food web in an atoll lagoon. Aquat Microb Ecol 16:53-64

Hansen PJ (1992) Prey size selection, feeding rates and growth dynamics of heterotrophic dinoflagellates with special emphasis on Gyrodinium spirale. Mar Biol 114: 327-334

Hansen PJ, Calado AJ (1999) Phagotrophic mechanisms and prey selection in free-living dinoflagellates. J Eukaryot Microbiol 46:382-389

Hansen PJ, Bjornsen PK, Hansen BW (1997) Zooplankton grazing and growth: scaling within the $2-2000-\mu \mathrm{m}$ body size range. Limnol Oceanogr 42:687-704

Heinbokel JF (1978) Studies on the functional role of tintinnids in the Southern California Bight. I. Grazing and growth rates in laboratory cultures. Mar Biol 47:177-189

Jeong HJ (1995) The interactions between microzooplanktonic grazers and dinoflagellates causing red tides in the open coastal waters off southern California. PhD thesis, University of California, San Diego, CA

Jeong HJ (1999) The ecological roles of heterotrophic dino- flagellates in marine planktonic community. J Eukaryot Microbiol 46:390-396

Jeong HJ, Latz MI (1994) Growth and grazing rates of the heterotrophic dinoflagellates Protoperidinium spp. on red tide dinoflagellates. Mar Ecol Prog Ser 106:173-185

Jeong HJ, Lee CW, Yih WH, Kim JS (1997) Fragilidium cf. mexicanum, a thecate mixotrophic dinoflagellate which is prey for and a predator on co-occurring thecate heterotrophic dinoflagellate Protoperidinium cf. divergens. Mar Ecol Prog Ser 151:299-305

Jeong HJ, Shim JH, Lee CW, Kim JS, Koh SM (1999) Growth and grazing rates of the marine planktonic ciliate Strombidinopsis sp. on red-tide and toxic dinoflagellates. J Eukaryot Microbiol 46:69-76

Jeong HJ, Kang HJ, Shim JH, Park JK, Kim JS, Song JY, Choi HJ (2001a) Interactions among the toxic dinoflagellate Amphidinium carterae, the heterotrophic dinoflagellate Oxyrrhis marina, and the calanoid copepods Acartia spp. Mar Ecol Prog Ser 218:77-86

Jeong HJ, Kim SK, Kim JS, Kim ST, Yoo YD, Yoon JY (2001b) Growth and grazing rates of the heterotrophic dinoflagellate Polykrikos kofoidii on red-tide and toxic dinoflagellates. J Eukaryot Microbiol 48:298-308

Jeong HJ, Kim JS, Yoo YD, Kim ST and 6 others (2003) Feeding by the heterotrophic dinoflagellate Oxyrrhis marina on the red-tide raphidophyte Heterosigma akashiwo: a potential biological method to control red tides using mass-cultured grazers. J Eukaryot Microbiol 50: $274-282$

Jeong HJ, You YD, Kim JS, Kang NS, Kim TH, Kim JH (2004a) Feeding by the marine planktonic ciliate Strombidinopsis jeokjo on common heterotrophic dinoflagellates. Aquat Microb Ecol 36:181-187

Jeong HJ, Yoo YD, Kim ST, Kang NS (2004b) Feeding by the heterotrophic dinoflagellate Protoperidinium bipes on the diatom Skeletonema costatum. Aquat Microb Ecol 36: 171-179

Jeong HJ, Kim JS, Kim JH, Kim ST, Seong KA, Kim TH, Song JY, Kim SK (2005a) Feeding and grazing impact of the newly described heterotrophic dinoflagellate Stoeckeria algicida on the harmful alga Heterosigma akashiwo. Mar Ecol Prog Ser 295:69-78

Jeong HJ, Kim JS, Park JY, Kim JH and 5 others (2005b) Stoeckeria algicida n. gen., n. sp. (Dinophyceae) from the coastal waters off southern Korea: morphology and small subunit ribosomal DNA gene sequence. J Eukaryot Microbiol 52:382-390

Jeong HJ, Park JY, Rho JH, Park MO and 5 others (2005c) Feeding by the red-tide dinoflagellates on the cyanobacterium Synechococcus. Aquat Microb Ecol 41:131-143

Jeong HJ, Ha JH, Park JY, Kim JH and 5 others (2006) Distribution of the heterotrophic dinoflagellate Pfieteria piscicida in Korean waters and its feeding on mixotrophic dinoflagellates, raphidophytes, and fish blood cells. Aquat Microb Ecol 44:263-278

Jeong HJ, Ha JH, Yoo YD, Park JY and 5 others (2007) Feeding by the Pfiesteria-like heterotrophic dinoflagellate Luciella masanensis. J Eukaryot Microbiol (in press)

Jürgens K, Wickham SA, Rothhaupt KO, Santer B (1996) Feeding rates of macro- and microzooplankton on heterotrophic nanoflagellates. Limnol Oceanogr 41: 1833-1839

Kim JS, Jeong HJ (2004) Feeding by the heterotrophic dinoflagellates Gyrodinium dominans and G. spirale on the red-tide dinoflagellate Prorocentrum minimum. Mar Ecol Prog Ser 280:85-94

Lessard EJ (1991) The trophic role of heterotrophic dinofla- 
gellates in diverse marine environments. Mar Microb Food Web 5:49-58

Litaker RW, Steidinger KA, Mason PL, Landsberg JH and 7 others (2005) The reclassification of Pfiesteria shumwayae (Dinophyceae): Pseudopfiesteria, gen. nov. J Phycol 41: 643-651

Mason PL, Litaker RW, Jeong HJ, Ha JH and 8 others (2007) Description of a new genus of Pfiesteria-like dinoflagellate, Luciella gen. nov. (dinophyceae), including two new species: Luciella masanensis sp. nov. and Luciella atlantis sp. nov. J Phycol (in press)

Menden-Deuer S, Lessard E (2000) Carbon to volume relationships for dinoflagellates, diatoms, and other protist plankton. Limnol Oceanogr 45:569-579

Patterson DJ, Larsen J (1991) General introduction. In: Patterson DJ, Larsen J (eds) The biology of free-living heterotrophic flagellates. Systematics Association Spec Vol 45, Clarendon Press, Oxford, p 1-5

Sanders RW, Leeper DA, King CH, Porter KG (1994) Grazing by rotifers and crustacean zooplankton on nanoplanktonic protists. Hydrobiologia 288:167-181

Seong KA, Jeong HJ, Kim S, Kim GH, Kang JH (2006) Bacterivory by co-occurring red-tide algae, heterotrophic nanoflagellates, and ciliates. Mar Ecol Prog Ser 322:85-91

Sherr EB, Sherr BF (2000) Marine microbes. An overview. In: Kirchman DL (ed) Microbial ecology of the oceans. Wiley-Liss, New York, p 13-46

Sherr BF, Sherr EB, Fallon RD (1987) Use of monodispersed, fluorescently labeled bacteria to estimate in situ protozoan bacterivory. Appl Environ Microbiol 53:958-965

Sherr EB, Rassoulzadegan F, Sherr BF (1989) Bacterivory by pelagic choreotrichous ciliates in coastal waters of the NW Mediterranean Sea. Mar Ecol Prog Ser 55:235-240

Editorial responsibility: Barry \& Evelyn Sherr (Contributing Editors), Corvallis, Oregon, USA
Sieburth JM (1984) Protozoan bacterivory in pelagic marine waters. In: Hobbie JE, Williams PJ leB (eds) Heterotrophic activity in the sea. Plenum Publishing, New York, p 405-444

Šoliç M, Krstuloviç N (1994) Role of predation in controlling bacterial and heterotrophic nanoflagellate standing stocks in the coastal Adriatic Sea: seasonal patterns. Mar Ecol Prog Ser 114:219-235

Steidinger KA, Burkholder JM, Glasgow HB Jr, Hobbs CW, Garrett JK, Truby EW, Noga EJ, Smith SA (1996) Pfiesteria piscicida gen. et sp. nov. (Pfiesteriaceae fam. nov.), a new toxic dinoflagellate with a complex life cycle and behavior. J Phycol 32:157-164

Strom SL, Buskey EJ (1993) Feeding, growth, and behavior of the thecate heterotrophic dinoflagellate Oblea rotunda. Limnol Oceanogr 38:965-977

Tillmann U (2004) Interactions between planktonic microalgae and protozoan grazers. J Eukaryot Microbiol 51: $156-168$

Tillmann U, Reckermann M (2002) Dinoflagellate grazing on the raphidophyte Fibrocapsa japonica. Aquat Microb Ecol 26:247-257

Turner JT, Tester PA, Ferguson RL (1988) The marine cladoceran Penilia avirostris and the 'microbial loop' of pelagic food webs. Limnol Oceanogr 33:245-255

Vaque D, Calderon-Paz JI, Guixa-Boixereu N, Pedros-Alio C (2002) Spatial distribution of microbial biomass and activity (bacterivory and bacterial production) in the northern Weddell Sea during the austral summer (January 1994). Aquat Microb Ecol 29:107-121

Verity PG (1991) Measurement and simulation of prey uptake by marine planktonic ciliates fed plastidic and aplastidic nanoplankton. Limnol Oceanogr 36:729-750

Submitted: May 19, 2006; Accepted: August 14, 2006

Proofs received from author(s): February 22, 2007 